\title{
Integrating Career Development Into The Accounting Curriculum
}

Susan B. Wessels, Meredith College, USA

Dana F. Sumner, Meredith College, USA

\begin{abstract}
This paper describes a series of integrated career development activities offered in several required courses which are designed to help accounting majors gain a competitive edge in the job market. Supported by a partnership between the School of Business and the Academic and Career Planning Office, the Career Tool Kit program consists of classroom presentations followed by hands-on applied experiences in which students become proficient in preparing resumes, writing cover letters, interviewing, and using all available resources to find a position that best matches their skills, interests, and values. Unique features of the Career Tool Kit are the placement of program elements within required courses (to ensure that all students participate) and the scheduling of these elements over a three-year period (to allow time for students to prepare an intentional job search strategy).
\end{abstract}

Keywords: Accounting Curriculum; Career Development; Job Search; Resume; Mock Interview

\section{INTRODUCTION}

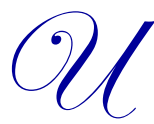

ndergraduate students face a daunting job market. A 2013 employer survey conducted by the National Association of Colleges and Employers (NACE) found employers "expected to hire only 2.1 percent more college graduates from the class of 2013 than they did from the class of 2012" (NACE, April 17, 2013). This figure was well below the 13 percent hiring increase projected in Fall 2012. The Wall Street Journal reported that employers have also reduced their on-campus recruiting visits (Wall Street Journal, August 5, 2011) which places even more pressure on Career Services staff. College students are competing for entry-level jobs not only with recent graduates but also with those who have been in the workforce for several years.

The employment outlook is not as bleak for students who major in technical fields such as accounting. According to projections by the Bureau of Labor Statistics, demand for workers in accounting will continue to be strong through 2020. A 2013 survey conducted by the American Institute of Certified Public Accountants (AICPA) reported that those with accounting degrees are enjoying an unprecedented level of demand. It noted, however, that employers increasingly favor those with masters degrees. In the last 10 years, the number of graduates with masters degrees in accounting has more than doubled (Moore, 2013).

Undergraduate accounting majors who do not plan to pursue a master's degree may be lulled by media reports into a false sense of security about their job prospects. Having read the headlines about increased demand for accountants, they believe that a suitable position will magically appear. Like many college students, they may have a tendency to procrastinate, waiting until their last semester to begin a serious job search. There are several reasons why students may delay a job search. Vinton (1992) noted that some have fears about their future (such as their chosen direction within their field) or fears about failure (related to concerns about making enough money to pay off debts). Others may feel overwhelmed or uncertain about to conduct a full-fledged job search. And finally, there are some students who have time pressures caused by the need to balance heavy course loads and part-time positions which result in little time to prepare for a successful job search.

In order to navigate today's turbulent job market, accounting students need to develop job search skills that will yield attractive employment offers. The challenge for accounting educators is to find ways to motivate all students to engage in development activities well before graduation. 


\section{CURRENT PRACTICES}

To help students prepare for their first position after college, most institutions offer a variety of activities, such as a resume workshop, career panels, or networking events, typically at the end of the students' college program. Many times these types of events are the responsibility of Career Services and are offered to students of any major.

At some institutions, the accounting faculty have developed activities more focused on the needs of accounting students. Kilpatrick and Wilburn (2010) describe their experience at Northern Arizona University in using mock interviews with accounting professionals who provided targeted feedback. Another approach is the daylong "boot camp" for new accounting majors used at Ball State University (Myring, Wrege, \& Van Alst, 2008). In one of the sessions young alumni provide information about interviewing, proper dress, and soft skills. Others have included job search skills as part of a broader program on the accounting profession. A semester length workshop at Loyola University called "Preparing for the Profession" includes one session focused on various elements of the recruiting process such as researching a firm, the interview day, professional follow-up, dining etiquette, and business attire (Landgraf, Stanko, \& Jinkerson, 2012).

A senior capstone course can be used to integrate discipline specific content and employment skills. Students in the Communication and Leadership Development program at the University of Florida participate in a capstone course that combines experiential learning opportunities in the discipline and a career development unit including resume preparation and mock interviews (Gifford et al., 2011). A capstone course has the advantage of exposing all majors to employment skills, but its impact may be lessened by the fact that capstone courses are often taken in the senior year at which point it may be too late. Accounting job searches usually begin early in the Fall semester. Perhaps for this reason, the focus of capstone courses in accounting programs rarely involve employment skills (Ehoff, 2010; Jervis \& Hartley, 2005).

Instead of a capstone course, Addams and Woodbury (2009) discussed the use of a business communication course to offer an integrated approach to teaching job search written and oral communication skills. Students found a real job announcement and then created a suitable resume and cover letter. Students then conducted mock interviews of each other and wrote about their strengths and weaknesses as an interviewee.

McCorkle et al. (2003) recommend that faculty "strengthen ties with their university's career services." Students may not be aware that the role of the campus career office extends beyond facilitating job interviews. Career services professionals can offer assistance with career planning and counseling, job shadowing, mentoring, alumni networking and career fairs. Yeadon (2009-2010) noted that "student affairs professionals can help students gain skills employers are looking for that have not been fully developed in academic settings." Career services staff can partner with accounting educators to offer instruction on resume preparation, cover letters, and interviewing. This type of partnership overcomes the difficulty faced by career services professionals who must tailor their presentations to the specific major being served. A resume that is appropriate for creative positions will be quite different from a resume submitted for a financial position.

\section{AN INTEGRATED APPROACH TO DEVELOPING JOB SEARCH SKILLS}

In the past, the professional staff from the Academic and Career Planning (ACP) Office were invited to several Business School classes to speak about placement services, resume preparation or cover letters. However, scheduling was irregular, and the topic was chosen by the instructor. Sometimes students would hear a presentation on resume writing in two different classes in the same semester. These presentations were very well received by students, but there was little chance for follow-up in which they could apply concepts. We also observed some seniors missing out on great job opportunities because they did not have a professional resume ready in time when positions were announced or they were ill-at-ease and unprepared during on campus interviews. Others would wait until after graduation to begin looking for a job. We decided that we needed to create a program for our students that would be facilitated throughout their college career beginning with their first major course. It was important to infuse this program into the curriculum and intentionally focus on career topics at the appropriate time during a student's academic path. Our goal was a program that provided students with the opportunity to gain relevant and 
applicable career related skills and would utilize the expertise of accounting and business faculty and ACP staff to focus on the needs of students planning for careers in the business world.

There were several hurdles to overcome in creating a program to prepare students for an effective job search. The first hurdle was to construct the experience so that all students will be likely to participate. Because of part-time jobs, family responsibilities, or just inertia, co-curricular programs with voluntary attendance may not be as successful as a required course. Unfortunately, it is difficult to find space in the accounting curriculum for another course. Other hurdles involved providing a systematic way to build upon and reinforce prior training and offering opportunities for students to apply the information and receive feedback so that they might conduct an intentional job search.

\section{THE CAREER TOOL KIT FOR ACCOUNTING MAJORS}

The Career Tool Kit program is a series of integrated career development activities offered within several required major courses which are designed to help students gain a competitive edge in the job market. Supported by a partnership between the Academic and Career Planning (ACP) Office and the School of Business, the program consists of eight elements as described below.

\section{Strengthening Qualifications}

In the Data Analysis course students explore ways to strengthen qualifications through networking, volunteering, club participation, career events and programs and professional meetings. The ACP staff member leads a discussion about online resources which provide students with knowledge about internships, co-ops, full time and part-time positions, on campus recruiting, and networking contacts. The focus is on ways students can become more competitive.

\section{Creating a Resume}

In Financial Accounting students participate in a hands-on workshop led by a staff member from the ACP Office to help them create an effective and powerful resume. They learn how to build a resume around leadership, study abroad, volunteering, and internships and are challenged to think of intentional ways to gain needed experience in order to be competitive after college. After the presentation, students prepare a resume and take it to the ACP Office to be critiqued. The revised resume is then submitted to the instructor.

\section{Expanding Career Horizons}

Students are not always clear about the variety of positions open to accounting majors and they are only vaguely aware of professional credentials. In Intermediate Accounting I they interview a CPA and in Intermediate II they interview someone with another professional certification such as a CIA, CMA, or CFE. The purpose of this assignment is to learn about the individual's education and experience, the industry or field in which this accountant works, the types of employers who might offer similar jobs, and to get advice about their own career path. They prepare a five page paper describing their findings and conclude with a reflection about whether they are more or less likely to become a CPA (or CIA, CMA, CFE) and why. These projects are always cited by students on the course evaluations as the single most meaningful assignment of the course. As a result of these projects, students who were thinking of changing majors have decided to remain in accounting while others found out about specialties in the field that better fit their skills.

\section{Enhancing Written Communication with Employers}

A cover letter is often the first thing a hiring manager or a recruiter sees. Students in the Operations Management class capitalize on this chance to shine by creating a letter that will open the door to an interview. During class the ACP staff member illustrates the components of effective letters. Students discuss elements in their letters that they believe appropriately use the strategies and techniques of a well written letter that will catch the attention of the employer. Based on the techniques discussed in class, students are required to revise their cover letter and submit it to ACP where it undergoes a final review. 


\section{Developing Oral Communication Skills}

An ACP staff member provides information to Organizational Behavior classes about the steps in preparing for each stage of an interview - before, during, and afterward. Types of questions candidates may be asked, along with types of questions they could be asked are also reviewed. As time permits, students practice responding to sample interview questions in class. Then using these verbal and non-verbal communication skills, students practice their interviewing skills by participating in a mock interview conducted by accounting and business professionals. These interviews are arranged by ACP and held in their offices to simulate a real interview. Students and the instructor receive an evaluation form that the professional completes after each interview which offers feedback about how to improve performance.

Another element of communication involves being prepared for a short, informal encounter with a prospective employer. Students in Intermediate Accounting draft a "30-second commercial" about themselves for use at networking events or at professional meetings. The students gather in small groups with a professional to receive candid, constructive criticism and tips for improvement. Based on the feedback received, students then present their revised commercials to the entire group followed by final thoughts and recommendations from the professionals.

\section{Employing Effective Job Search Strategies}

The key strategies that students should consider when conducting a job search is the focus in Corporate Finance. The ACP staff member helps students better understand the process of job searching and how to become competitive. Key components of this presentation include self assessment, employer research, tailoring contacts, networking, and how to best to present oneself in a professional manner. Students are required to research and find a position description with an organization that interests them and respond to specific questions about the strengths and skills they currently possess that fit with the position and organization. In addition they are to identify the mission and values of the organization and how it relates to what they find important in the work they want to do, the work values that might be found in this position or at this organization that might match or conflict with personal values, and what steps are needed to prepare for this position. This writing assignment allows students to reflect on where they are in the job search process and where they need or want to be.

\section{Gaining Practical Experience}

Employers increasingly focus their hiring efforts on those whom they know through internships. Our internships are in the form of a three-credit course requiring at least 120 hours of supervised work experience related to the student's major. The work performed during the internship must be of a professional nature and the duties must be approved by the instructor. As part of the internship course, students use the resume and cover letter prepared in earlier classes and must interview with the company offering the internship. Once hired, the student interns work under a site supervisor and the instructor. This faculty member makes periodic visits to the internship site to evaluate the student's performance, receives a weekly email report from the student about the experience, and facilities monthly group meetings on campus of the interns. At the end of the internship, the site supervisor evaluates the work performed by the student using an evaluation form. Students write a paper reflecting on their experience.

\section{Co-Curricular Events}

In addition to mandatory activities described above, students have several opportunities outside of class to gain additional career-related skills. Our SHRM student chapter sponsors an annual Business Attire Fashion Show. Student models demonstrate "do's" and "don'ts" in the business world for both interviews and "casual Fridays." Students participate in a variety of networking events and career fairs with employers and alumnae and beforehand, are properly trained to positively interact with these professionals. In addition, Academic \& Career Planning offers supplementary workshops and one-on-one practice sessions for students to gain the necessary skills to increase their network. These conversations help students appropriately and actively use LinkedIn, prepare and practice for upcoming career fairs and mock interviews, and learn how to best incorporate their strengths into their careers for professional and personal well-being. 


\section{STUDENT PERCEPTIONS OF THE CAREER TOOL KIT}

Three years after implementing the Career Tool Kit, we conducted a survey of students enrolled in Fall 2012 classes to determine their perceptions of its usefulness and effectiveness. A total of 118 surveys were completed (from five different classes) which represented a response rate of 79.7 percent. The student perceptions and a summary of their open-ended comments are presented below for five of eight elements of the Career Tool Kit.

Table 1a: Strengthening Qualifications - Student Perceptions

\begin{tabular}{|l|c|c|c|c|c|}
\hline \multicolumn{2}{|c|}{$\begin{array}{c}\text { Strongly } \\
\text { Agree }\end{array}$} & Agree & $\begin{array}{c}\text { Neither Agree } \\
\text { or Disagree }\end{array}$ & Disagree & $\begin{array}{c}\text { Strongly } \\
\text { Disagree }\end{array}$ \\
\hline \multicolumn{5}{|c|}{--Percent Responding-- } \\
\hline I am aware of the components of the career planning process & $68.2 \%$ & $31.8 \%$ & 0 & 0 & 0 \\
\hline $\begin{array}{l}\text { I better understand what I can do to learn more about my } \\
\text { career options including conducting an information interview }\end{array}$ & $77.3 \%$ & $22.7 \%$ & 0 & 0 & 0 \\
\hline $\begin{array}{l}\text { I am prepared to conduct an information interview with a } \\
\text { professional of my choice }\end{array}$ & $45 . \% \%$ & $50.0 \%$ & $4.5 \%$ & 0 & 0 \\
\hline
\end{tabular}

Table 1b: Strengthening Qualifications - Self-Reported Behavioral Change

\begin{tabular}{|l|c|}
\hline \multicolumn{1}{|c|}{$\begin{array}{c}\text { "As a result of this presentation, I will...." } \\
\text { (summary of open-ended responses) }\end{array}$} & Percent Responding \\
\hline Get an internship or look for work experience related to my field & $46 \%$ \\
\hline Make more connections through clubs, networking, and volunteer opportunities & $29 \%$ \\
\hline Make appointment at the ACP Office and learn to use Career Link & $25 \%$ \\
\hline
\end{tabular}

Data Analysis is one of the first courses taken by majors. Students are mostly sophomores who are not generally aware of how to get a job search started. The purpose of this module is to familiarize students with the services of the Academic and Career Planning (ACP) Office and to motivate them to begin acquiring the kinds of experiences needed in their intended career. Based on the survey, it appears that students intend to follow through.

Table 2a: Creating a Resume - Student Perceptions

\begin{tabular}{|l|c|c|c|c|c|}
\hline \multicolumn{1}{|c|}{ As a result of this presentation..... } & $\begin{array}{c}\text { Strongly } \\
\text { Agree }\end{array}$ & Agree & $\begin{array}{c}\text { Neither Agree } \\
\text { or Disagree }\end{array}$ & Disagree & $\begin{array}{c}\text { Strongly } \\
\text { Disagree }\end{array}$ \\
\hline \multicolumn{3}{|c|}{--Percent Responding-- } \\
\hline $\begin{array}{l}\text { I have a better idea of the section and content I should } \\
\text { include in my own resume }\end{array}$ & $64.3 \%$ & $33.3 \%$ & $2.4 \%$ & 0 & 0 \\
\hline $\begin{array}{l}\text { I notice areas in which I can increase my experience and } \\
\text { skill set to be a more competitive candidate }\end{array}$ & $64.3 \%$ & $30.9 \%$ & $4.8 \%$ & 0 & 0 \\
\hline $\begin{array}{l}\text { I have a better idea about what an employer wants to see on } \\
\text { my resume and ways I can better focus it for him/her }\end{array}$ & $50.0 \%$ & $42.9 \%$ & $7.1 \%$ & 0 & 0 \\
\hline
\end{tabular}

Table 2b: Creating a Resume - Self-Reported Behavioral Change

\begin{tabular}{|l|c|}
\hline \multicolumn{1}{|c|}{$\begin{array}{c}\text { "As a result of this presentation, I will....” } \\
\text { (summary of open-ended responses) }\end{array}$} & Percent Responding \\
\hline Create, improve, or rethink my resume to make it more professional & $67 \%$ \\
\hline Change or tweak my resume for different positions & $14 \%$ \\
\hline Make an appointment at the Career Center for additional help & $10 \%$ \\
\hline Enhance my resume by focusing on areas needing improvement (like Excel) & $7 \%$ \\
\hline Other & $2 \%$ \\
\hline
\end{tabular}

Another sophomore level course, Financial Accounting, is a good place to introduce the concepts needed to prepare a professional resume. After the presentation, students prepare a resume and have it reviewed by ACP staff. It gives students a significant advantage to have a polished resume prepared during their second year so that they can act quickly if an internship or other work opportunity should become available. This presentation also reinforces the message that to be a viable candidate, they need to have something more than just good grades. 
Table 3a: Enhancing Written Communication with Employers - Student Perceptions

\begin{tabular}{|c|c|c|c|c|c|}
\hline & $\begin{array}{l}\text { Strongly } \\
\text { Agree }\end{array}$ & Agree & $\begin{array}{c}\text { Neither Agree } \\
\text { or Disagree }\end{array}$ & Disagree & $\begin{array}{l}\text { Strongly } \\
\text { Disagree }\end{array}$ \\
\hline As a result of this presentation..... & \multicolumn{5}{|c|}{--Percent Responding-- } \\
\hline I understand what should be included in a cover letter & $65.2 \%$ & $30.4 \%$ & $4.4 \%$ & 0 & 0 \\
\hline $\begin{array}{l}\text { I know how to highlight my education, skills, impact made, } \\
\text { value added, and/or experiences in a cover letter (what I can } \\
\text { do for the employer rather than what they can do for me) }\end{array}$ & $60.9 \%$ & $39.1 \%$ & 0 & 0 & 0 \\
\hline $\begin{array}{l}\text { I know appropriate language and phrases that could be } \\
\text { included in a cover letter. }\end{array}$ & $56.5 \%$ & $39.1 \%$ & $4.4 \%$ & 0 & 0 \\
\hline
\end{tabular}

Table 3b: Enhancing Written Communication with Employers - Self-Reported Behavioral Change

\begin{tabular}{|l|c|}
\hline \multicolumn{1}{|c|}{$\begin{array}{c}\text { "As a result of this presentation, I will...." } \\
\text { (summary of opened-ended responses) }\end{array}$} & Percent Responding \\
\hline Fix or revise my cover letter; write a more effective cover letter & $65 \%$ \\
\hline $\begin{array}{l}\text { Understand the importance of tailoring my experience and skills to the job; do more research on the } \\
\text { needs of employer }\end{array}$ & $17 \%$ \\
\hline Use proper format to make letter more professional & $17 \%$ \\
\hline Other & $1 \%$ \\
\hline
\end{tabular}

Students in junior-level courses like Operations Management, are eager for internships and know that they need help in crafting a cover letter that will differentiate them from the competition. In addition to the class presentation, students review letters of their peers. They find it helpful to see how others are choosing to present themselves and enjoy discussing ways to improve. Final versions of the cover letters are reviewed by ACP staff.

Table 4a: Developing Oral Communication with Employers - Student Perceptions

\begin{tabular}{|l|c|c|c|c|c|}
\hline \multicolumn{1}{|c|}{ As a result of this presentation..... } & $\begin{array}{c}\text { Strongly } \\
\text { Agree }\end{array}$ & Agree & $\begin{array}{c}\text { Neither Agree } \\
\text { or Disagree }\end{array}$ & Disagree & $\begin{array}{l}\text { Strongly } \\
\text { Disagree }\end{array}$ \\
\hline \multicolumn{3}{|c|}{--Percent Responding-- } \\
\hline I understand the major components of interviewing & $77.8 \%$ & $22.2 \%$ & 0 & 0 & 0 \\
\hline I know how to prepare for an interview & $66.7 \%$ & $33.3 \%$ & 0 & 0 & 0 \\
\hline $\begin{array}{l}\text { I now know how I can highlight my education, skills, } \\
\text { impact made, value added, and/or experiences in an } \\
\text { interview }\end{array}$ & $66.7 \%$ & $27.8 \%$ & $5.5 \%$ & 0 & 0 \\
\hline
\end{tabular}

Table 4b: Developing Oral Communication with Employers - Self-Reported Behavioral Change

\begin{tabular}{|l|c|}
\hline \multicolumn{1}{|c|}{\begin{tabular}{c}
\multicolumn{1}{|c|}{$\begin{array}{c}\text { "As a result of this presentation, I will...." } \\
\text { (summary of open-ended responses) }\end{array}$} \\
\hline Be more confident; more comfortable; do well on interview
\end{tabular}} \\
\hline Practice interviewing skills beforehand & $41 \%$ \\
\hline $\begin{array}{l}\text { Do company research beforehand so I can present myself well; work on resume and practice } \\
\text { discussing past experience }\end{array}$ & $24 \%$ \\
\hline
\end{tabular}

Discussing interviewing techniques used by employers and the best strategy for dealing with difficult or unexpected situations fits perfectly in an Organizational Behavior class. Students then have an opportunity to apply what they learned by undergoing a mock interview with a professional from the business world. Some students have found this experience so valuable that they have volunteered to participate in additional sessions. Completing a mock interview in the junior year gives students more time to develop the confidence and poise needed for actual job interviews in the senior year. 
Table 5a: Employing Effective Job Search Strategies - Student Perceptions

\begin{tabular}{|l|c|c|c|c|c|}
\hline & $\begin{array}{c}\text { Strongly } \\
\text { Agree }\end{array}$ & Agree & $\begin{array}{c}\text { Neither Agree } \\
\text { or Disagree }\end{array}$ & Disagree & $\begin{array}{c}\text { Strongly } \\
\text { Disagree }\end{array}$ \\
\hline As a result of this presentation..... & \multicolumn{5}{|c|}{--Percent Responding-- } \\
\hline $\begin{array}{l}\text { I have a better understanding about how to approach my } \\
\text { job or internship search }\end{array}$ & $57.1 \%$ & $42.9 \%$ & 0 & 0 & 0 \\
\hline $\begin{array}{l}\text { I know of several way I can explore and investigate } \\
\text { employers that might be a fit for me }\end{array}$ & $78.6 \%$ & $21.4 \%$ & 0 & 0 & 0 \\
\hline $\begin{array}{l}\text { I realize the multiple (positive) ways I can get noticed } \\
\text { by employers. }\end{array}$ & $57.1 \%$ & $42.9 \%$ & 0 & 0 & 0 \\
\hline
\end{tabular}

Table 5b: Employing Effective Job Search Strategies - Self-Reported Behavioral Change

\begin{tabular}{|c|c|}
\hline $\begin{array}{c}\text { "As a result of this presentation, I will...." } \\
\text { (summary) }\end{array}$ & Percent Responding \\
\hline $\begin{array}{l}\text { Be more active in my job search; seek employers that best fit my work values; be more active on } \\
\text { Linked-in. }\end{array}$ & $31 \%$ \\
\hline $\begin{array}{l}\text { Keep a journal about prospective employers; start a list of companies and jobs; do more research } \\
\text { on employers }\end{array}$ & $31 \%$ \\
\hline Be able to find a job because of a better understanding of the search process & $15 \%$ \\
\hline
\end{tabular}

As students enter their senior year, they need to expand their search but many do not know how to systematically do this. In Corporate Finance, they discuss job titles and related kinds of jobs, the types of firms that might have appropriate positions, and how to use online sources, networking, and other connections. Again, we think it is important to have an applied, skill-building activity. In this case, students must find a position announcement/opening and write a reflection piece about the firm's mission and values including how the position might fit with their own interests, skills, and work values.

\section{EMPLOYER PERCEPTIONS OF THE CAREER TOOL KIT}

We surveyed employers who recruit at our institution for full-time, part-time, and internship positions. They were asked to indicate the discipline(s) or major(s) they typically hire. There were 69 respondents and 18 of them indicated a first or second choice major in accounting or one of the business fields (these students also participate in the Career Tool Kit program). The employers were asked how satisfied they are with their Meredith student/alumnae hires compared to those they have hired from other institutions using a rating scale in which 5 means "Very Satisfied;" 4 means "Satisfied;" 3 means "Somewhat Satisfied;" 2 means "Dissatisfied;" and 1 means "Very Dissatisfied." The results showed that employers in general were highly satisfied with Meredith College students. Employers hiring accounting/business majors expressed higher levels of satisfaction in all categories than employers who hired other majors, but in only one category was this difference significant. An independent samples t-test compared the employer satisfaction scores for accounting/business majors with that of other majors. The results are reported in Table 6 "Recruitment Survey 2013." We found a statistically significant difference on the category "maturity and performance during the interview," for accounting/business majors compared to other majors.

The results suggest that the Career Tool Kit has had a positive impact but are not conclusive because of the lack of statistical significance. There was little difference between the Career Tool Kit students and other majors on resume writing perhaps because most students understand the importance of a well-written resume. Also, the ACP Office provides strong support for resume writing to all students by means of drop-in clinics and workshops.

On the other hand, employers were significantly more satisfied with the interview performance of Career Tool Kit students compared to other students. It appears that the mock interview portion of the toolkit is a "turning point" for students. After they have that experience, they are more poised and polished in both their formal and informal communication with employers. Their confidence also seems to be stronger, as well. Although the ACP Office offers to all students the opportunity to participate in mock interviews, only the Career Tool Kit students are required to do so. For reasons cited earlier, other students may start their job search too late to allow time to participate in mock interviews. The improved performance of the Career Tool Kit students may result not only from the requirement to participate but also from the scheduling of this experience, usually in the junior year. 
Table 6: Recruitment Survey 2013

\begin{tabular}{|c|c|c|c|c|c|}
\hline & \multicolumn{2}{|c|}{$\begin{array}{c}\text { Employers of Accounting or } \\
\text { Business Majors }\end{array}$} & \multicolumn{2}{|c|}{ Employers of Other Majors } & \multirow[b]{2}{*}{ Significance } \\
\hline & $\begin{array}{c}\text { Item Mean } \\
\text { (5 = Strongly } \\
\text { Agree })\end{array}$ & $\begin{array}{l}\text { Standard } \\
\text { Deviation }\end{array}$ & $\begin{array}{c}\text { Item Mean } \\
\text { (5 = Strongly } \\
\text { Agree) }\end{array}$ & $\begin{array}{l}\text { Standard } \\
\text { Deviation }\end{array}$ & \\
\hline Professional appearance and poise & 4.82 & 0.490 & 4.64 & 0.405 & $p=.30$ \\
\hline $\begin{array}{l}\text { Maturity and performance during the } \\
\text { interview }\end{array}$ & 4.83 & 0.389 & 4.38 & 0.495 & $p=.01$ \\
\hline Resume format and content & 4.50 & 0.674 & 4.41 & 0.666 & $p=.71$ \\
\hline Knowledge of your organization & 4.19 & 0.874 & 3.83 & 0.778 & $p=.24$ \\
\hline Knowledge of the position applied for & 4.08 & 0.669 & 3.92 & 0.759 & $p=.53$ \\
\hline $\begin{array}{l}\text { Previous experience } \\
\text { classroom, such as of the } \\
\text { research, internships, study abroad, } \\
\text { athletics, leadership, or volunteer } \\
\text { service }\end{array}$ & 4.45 & 0.522 & 4.14 & 0.710 & $p=.20$ \\
\hline
\end{tabular}

In the past year we added a required internship to the Career Tool Kit. As more students complete the mandatory internship, we anticipate employers' perceptions of students' previous experience to become significantly different between accounting/business majors and other majors.

Since the Career Tool Kit is relatively new, (one college generation) we expect student performance will continue to improve over time. We are considering ways to extend the program to other core courses such as principles of economics and principles of marketing. Our unit on strengthening qualifications in the Data Analysis course has been modified to allow students to practice conversations with others - entering a conversation, exiting a conversation, discussion through email about how they may introduce themselves to a prospective employer, at networking events, and so on. We are adding a unit on using social media in the job search which will improve students' knowledge of the firms and positions for which they apply. The Career Tool Kit will evolve in response to the needs of students.

\section{CONCLUSION}

Incorporating career development into the accounting curriculum has been an intentional and proactive way to teach career development and job search skills to all accounting students, especially as college students face a challenging job market. In particular, this provides students who are balancing a number of academic, job, and cocurricular responsibilities and who may not invest the time to seek out career services, the opportunity to increase their knowledge and gain necessary skills through career focused presentations and skill building exercises in their classes. The School of Business Career Toolkit provides the knowledge and skills critical to the success of students as they seek to obtain a job or admission to a graduate program by the time they graduate. The program is purposeful and emphasizes ways each student can take an individualized approach to her career plan and job search. The partnership between the School of Business and Academic \& Career Planning continues to assist students in strengthening their qualifications, creating and presenting appropriate documents, enhancing their written and verbal communication skills, and developing effective job search strategies.

\section{AUTHOR INFORMATION}

Susan B. Wessels is a professor of accounting at Meredith College and is also a Certified Public Accountant. E-mail: wesselss@ meredith.edu (Corresponding author)

Dana F. Sumner is Associate Director for Employer Relations at Meredith College. E-mail: SumnerD@meredith.edu 


\section{REFERENCES}

1. Addams, L., \& Woodbury, D., (2009). Teaching job search written and oral communication skills through an integrated approach. American Journal of Business Education, 2(4), 13-18.

2. Ehoff, C. (2010). Notes on accounting capstone course design: Contemporary issues versus case analysis enhances student interest and learning. Contemporary Issues in Education Research, 3(3), 59-62.

3. Gifford, G., Cannon, K., Stedman, N., \& Telg, R. (2011). Preparation for full-time employment: A capstone experience for students in leadership programs. Journal of Leadership Education, 10(1), 103-114.

4. Jervis, K., \& Hartley, C. (2005). Learning to design and teach an accounting capstone. Issues in Accounting Education, 20(4), 311-313.

5. Kilpatrick, B., \& Wilburn, N. (2010). Breaking the ice: Career development activities for accounting students. American Journal of Business Education, 3(11), 77-84.

6. Landgraf, E., Stanko, B., \& Jinkerson, D. (2012). Preparing for the profession: The accounting job search and beyond. Contemporary Issues in Education Research, 5(4), 315-325.

7. McCorkle, D., Alexander, J., Reardon, J., \& Kling, N. (2003). Developing self-marketing skills: Are marketing students prepared for the job search? Journal of Marketing Education, 25(3), 196-207.

8. Moore, S. (2013). 2013 Trends in the supply of accounting graduates and the demand for public accounting recruits. Durham, NC: American Institute of Certified Public Accountants.

9. Myring, M., Wrege, W., \& Van Alst, L. (2008). Accounting Boot Camp for College Juniors. College Teaching Methods \& Styles Journal, 4(3), 13-22.

10. National Association of Colleges and Employers. (2013, April). Job outlook spring update: Employers trim hiring projections. Bethlehem, PA.

11. Vinton, D. (1992). Helping students find time for the job search. Journal of Career Planning \& Employment, 52(3), 71-74.

12. Weigley, S. (2011, August 5). Employers recruiting off-campus. The Wall Street Journal. Retrieved from http://online.wsj.com/article/SB10001424053111904800304576476552817595120.html

13. Yeadon, C. (2010). College senior transition programs: Transitioning from college to workplace. Journal of Student Affairs, (XIX), 44-50. 
NOTES 